\title{
PERANCANGAN KERANGKA KERJA STANDAR PANGAN FUNGSIONAL UNTUK MEMBANTU PENYERAPAN KALSIUM
}

\section{Design of Functional Food Standard Framework to Help Calcium Absorption}

\author{
Ellia Kristiningrum ${ }^{1}$, Putty Anggraeni ${ }^{1}$, Arini Widyastuti ${ }^{2}$ dan Bety Wahyu Hapsari ${ }^{3}$ \\ ${ }^{1}$ Pusat Penelitian dan Pengembangan Standardisasi, Badan Standardisasi Nasional \\ Gedung I BPPT Lantai 12, Jalan M.H. Thamrin No. 8, Jakarta, Indonesia \\ 2 Direktorat Sistem Penerapan Standar dan Penilaian Kesesuaian, Badan Standardisasi Nasional \\ ${ }^{3}$ Direktorat Pengembangan Standar Agro, Kimia, Kesehatan dan Halal, Badan Standardisasi Nasional \\ e-mail: ellia@bsn.go.id
}

Diterima: 29 November 2018, Direvisi: 11 Februari 2019, Disetujui: 15 Februari 2019

\begin{abstract}
Abstrak
Pengembangan pangan fungsional di Indonesia sangat prospektif dan memiliki peluang dalam perdagangan ekspor, antara lain ke Jepang, Eropa, dan Amerika. Banyaknya penelitian dan pengembangan bahan baku sebagai pangan fungsional yang terbukti dapat membantu penyerapan kalsium yang harus didukung dengan keberadaan SNI sehingga akan memberikan peluang pasar yang lebih besar dan stabil. Keberadaan Standar Nasional Indoensia (SNI) dibutuhkan untuk memberikan peluang pasar yang lebih besar dan stabil bagi pengembangan bahan baku sebagai pangan fungsional yang dapat membantu penyerapan kalsium. Kajian mengenai metode perumusan SNI untuk dapat menghasilkan SNI yang dapat diterapkan oleh stakeholder sangat perlu dilakukan. Hambatan pada saat perumusan standar sering dihadapi pada tahap awal prosesnya karena kurangnya informasi tentang kebutuhan pemangku kepentingan dari perspektif yang berbeda yang dapat menyebabkan standar yang dirumuskan tidak diterima oleh konsensus. Penelitian ini bertujuan untuk mengetahui semua kebutuhan pemangku kepentingan dan mencari kesepakatan bersama untuk masing-masing pemangku kepentingan. Penelitian ini menggunakan metode FACTS (Framework for Analysis, Comparison, and Testing of Standards). Metode ini menyediakan sarana untuk menganalisis, membandingkan dan menguji standar yang akan dikembangkan. Penelitian ini menjelaskan bagaimana memanfaatkan model informasi untuk mengatasi tantangan yang terkait dengan pengembangan dan komunikasi standar. Penelitian ini menghasilkan kerangka kerja yang dapat digunakan sebagai acuan pada saat penyusunan standar terkait pangan fungsional. Penelitian ini merekomendasikan penyusunan $\mathrm{SNI}$ istilah - definisi pangan fungsional dan SNI formula pangan fungsional untuk membantu penyerapan kalsium, yang didalamnya mengatur tentang tata cara klaim pangan fungsional.
\end{abstract}

Kata kunci: FACTS, pangan fungsional, kalsium, standardisasi

\begin{abstract}
Development of functional food in Indonesia is very prospective and has opportunities in the export trade, among others, to Japan, Europe, and America. The amount of research and development of raw materials as functional foods which is proven to be able to help calcium absorption which must be supported by the existence of SNI so that it will provide greater and more stable market opportunities. Existence of Indonesian National Standards $(\mathrm{SNI})$ is needed to provide greater and more stable market opportunities for development raw materials as functional foods that can help calcium absorption. Study regarding the method of SNI formulation to be able to produce SNI that can be applied by Stakeholders really need to be done. Obstacles at standard formulation are often faced the initial stage of the process due to lack of information about stakeholder needs from different perspectives that can cause the formulated standard not to be accepted by consensus. The objective of this research is to know all the needs of stakeholders and look for them mutual agreement for each stakeholder. This study uses the FACTS method (Framework for Analysis, comparison, and Testing of Standards). This method provided a means to analyze, compare and test standards that will developed. This study explains how to use the information model for overcome challenges related to standard development and communication. This research produced a framework that can be used as a reference when setting standards related to functional food. This study recommends the preparation of SNI terms - food definitions functional and functional functional SNI formula to assist calcium absorption, which is in it regulates the procedures for functional food claims.
\end{abstract}

Keywords: FACTS, functional food, calcium, standardization 


\section{PENDAHULUAN}

Tulang merupakan struktur hidup yang didalamnya terdapat protein, mineral terutama kalsium dan fosfor. Kalsium merupakan mineral dengan jumlah terbesar yang terdapat dalam tubuh manusia, yaitu kurang lebih $1000 \mathrm{~g}$ (Gropper, Smith, \& Groff, 2009). Kebutuhan kalsium pada masa remaja sangat tinggi oleh karena masa pembentukan tulang terbesar terjadi pada masa ini. Suplai kalsium dari makanan menjadi sangat penting untuk memaksimalkan peak bone massa (PBM) dan menjaga keseimbangan jumlahnya dalam tubuh sehingga kebutuhannya yang sangat tinggi (Fikawati \& Syafiq, 2005).

Kekurangan asupan kalsium akan memberikan risiko penyakit osteoporosis yang seringkali ditandai dengan berkurangnya massa tulang dan adanya perubahan mikroarsitektur jaringan tulang yang berakibat menurunnya kekuatan tulang dan meningkatnya kerapuhan tulang serta risiko terjadinya patah tulang (Cooper, Westlake, \& Harvey, 2006). Pada dasarnya terdapat dua karakteristik dari osteoporosis, yaitu osteoporosis pasca menopause dan osteoporosis senilis (Brouns \& Vermeer, 2000). Studi epidemiologis yang dilakukan menunjukkan bahwa asupan zat gizi makro dan mikro dalam tubuh merupakan salah satu faktor yang dapat memperlambat kejadian osteoporosis di masa lanjut usia. Selain memenuhi asupan zat gizi, perlu juga memperhatikan aktivitas fisik. Menurut Hoeger \& Goeger, (2005) kurangnya aktivitas fisik pada seorang individu di masa muda akan berdampak pada penurunan kepadatan tulang di masa lanjut usia.

Osteoporosis merupakan kelainan kelambatan tulang yang umumnya terjadi pada orang berusia di atas 65 tahun. Hal ini karena orang tua memiliki tingkat penyembuhan yang relatif rendah dibandingkan orang muda. Kejadian patah tulang memiliki dampak yang signifikan terhadap kualitas hidup dan biaya perawatan, karena perawatan di rumah sakit dan rehabilitasi yang relatif lama. Periode terpenting untuk mengetahui massa tulang adalah usia antara masa remaja dan usia 30 tahun, jauh sebelum tanda-tanda osteoporosis menjadi jelas. Beberapa tindakan dapat dilakukan, salah satunya adalah dengan tindakan diet untuk memaksimalkan massa tulang di awal kehidupan dan mengurangi hilangnya massa tulang di kemudian hari (Brouns \& Vermeer, 2000).

Penelitian tentang asupan kalsium pada remaja di negara maju mengindikasikan bahwa remaja putri mempunyai risiko yang paling besar terhadap asupan kalsium yang tidak adekuat, dan asupan tersebut semakin menurun pada usia 10 17 tahun. Asupan kalsium yang tidak adekuat pada remaja putri merupakan masalah potensial karena akan menyebabkan berkurangnya cadangan kalsium dalam tulang. Fikawati \& Syafiq (2005) menyebutkan di Indonesia konsumsi kalsium pada remaja masih kurang dari Angka Kebutuhan Gizi (AKG) yang dianjurkan. Hal ini karena faktor jenis kelamin dan aktivitas fisik.

Perubahan pola makan yang terjadi sebagai akibat dari peningkatan kesejahteraan penduduk terus mendorong kesadaran masyarakat akan besarnya hubungan antara makanan dan kemungkinan terjadinya penyakit (Marsono, 2008). Kehadiran produk pangan di pasar yang diperkaya nutrisi dan kondusif untuk kesehatan, bukanlah peristiwa baru yang semakin dikenal dengan kelompok nutraceutical dan pangan fungsional (Castellini, Canavari, \& Pirazzoli, 2002). Aspek pangan fungsional yang penting adalah klaim bahwa produk pangan tersebut memiliki dampak kesehatan selain nilai gizi yang biasa (Jonas \& Beckmann, 1998). Berkembangnya teknologi pangan yang pesat menjadi salah satu faktor yang mendorong minat industri dalam pengembangan pangan fungsional. Keinginan konsumen dalam hubungan antara diet dan kesehatan telah meningkat secara substansial dalam beberapa tahun terakhir. Saat ini telah ada pengakuan bahwa jika dikombinasikan dengan gaya hidup sehat, pangan fungsional dapat memberikan kontribusi positif bagi kesehatan dan kesejahteraan. Saat ini konsumen telah menginginkan makanan yang memiliki potensi untuk meningkatkan kesehatan, meningkatkan umur panjang dan/atau mengurangi risiko, atau menunda timbulnya, penyakit (Harnedy \& Fitzgerald, 2012).

Dalam hal fungsi pangan fungsional untuk penyerapan kalsium, penelitian terdahulu telah menemukan prospektif pengembangan sumber bahan baku inulin yang telah terbukti dapat meningkatkan penyerapan kalsium pada usus tikus, sapi dan manusia (Herminiati, Rimbawan, Nurhayu, Mulyati, \& Astuti, 2013). Penelitian lain juga telah memberikan bukti dari ekstrak alga laut (MAE) yang dapat meningkatkan anti-osteoporosis dan menginduksi pembentukan tulang menggunakan model tikus dan sel induk sumsum tulang. Kemampuan MAE untuk menipiskan osteoporosis telah dilakukan oleh Wong et al (2015).

Beragamnya inovasi yang dilakukan oleh peneliti dan industri dalam melihat peluang pengembangan pangan fungsional perlu didukung dengan kebijakan pemerintah. Dukungan dapat diberikan dalam hal jaminan kualitas produk, keberterimaan produk dan perlindungan produsen sekaligus konsumen dalam bentuk pengawasan peredaran produk, salah satunya melalui kegiatan standardisasi yang di dalamnya termasuk perumusan SNI, penerapan SNI, dan penyusunan skema 
kerjasama Komite Akreditasi Nasional (KAN). Selanjutnya, semua tindakan ini perlu diikuti dengan promosi yang intensif untuk mendukung peningkatan pemasaran.

Standardisasi dalam perekonomian memainkan peran penting dalam memungkinkan industri terdistribusi secara global. Hubungan yang erat antara strategi pengembangan dan implementasi standar sangat penting untuk memastikan sebuah standar dapat diacu atau diadopsi secara global. Untuk menghasilkan standar yang dapat diacu tersebut, dalam proses pengembangan dan penerapannya didasarkan pada pemahaman yang jelas mengenai persyaratan informasi, pemodelan konsep dari sudut pandang yang berbeda dari pihak-pihak yang berkepentingan. Dalam teori pengembangan standar, International Electrotechnical Commission (IEC) mengusulkan proses standardisasi terdiri dari 3 (tiga) tahapan, yaitu pengembangan standar, penerapan standar, dan pemeliharaan standar (Witherell, Lee, Witherell, \& Lee, 2013).

Brouns \& Vermeer, (2000) menyimpulkan diperlukan peran dari badan pemerintah untuk mengembangkan strategi yang tepat dalam mendukung pengembangan pangan fungsional. Badan Standardisasi Nasional sebagai Lembaga pemerintah yang memiliki tanggung jawab terhadap pembinaan kegiatan standardisasi dan penilaian kesesuaian, dapat melaksanakan peran pemerintah dalam mengembangkan Standar Nasional Indonesia (SNI) yang nantinya dapat digunakan sebagai dasar penyusunan strategi yang tepat untuk mendukung pengembangan pangan fungsional untuk mencegah osteroporosis. Penelitian ini bertujuan untuk menyusun rancangan Standar Nasional Indonesia pangan fungsional menggunakan FACTS dengan mempertimbangkan semua kebutuhan stakeholder dan merekomendasikan variabel-variabel yang diperlukan dalam pengembangan standar pangan fungsional.

\section{TINJAUAN PUSTAKA}

\subsection{Penyerapan Kalsium}

Di dalam tubuh manusia, kalsium merupakan unsur terbanyak kelima dan kation terbanyak dengan jumlah sekitar 1,5-2\% dari keseluruhan berat tubuh. Kalsium di dalam tubuh berperan dalam proses pembentukan dan perawatan jaringan rangka tubuh serta membantu dalam pengaturan transport ion-ion lainnya ke dalam maupun ke luar membrane. Fungsi lain dari kalsium yaitu berperan dalam penerimaan dan interpretasi pada impuls saraf, pembekuan darah dan pemompaan darah, kontraksi otot, menjaga keseimbangan hormon dan katalisator pada reaksi biologis (Trilaksani, Salamah, \& Nabil, 2006).
Trilaksani et al., (2006) menyebutkan bahwa World Health Organization merekomendasikan jumlah asupan kalsium per hari yang dianjurkan untuk orang dewasa sekitar 400-500 mg tetapi bila konsumsi proteinnya tinggi dianjurkan mengkonsumsi $700-800 \mathrm{mg}$. Untuk anak-anak dan remaja lebih tinggi asupannya dan untuk wanita hamil atau menyusui dianjurkan mengkonsumsi $1200 \mathrm{mg}$. Konsumsi kalsium sebaiknya tidak melebihi $2500 \mathrm{mg}$ sehari untuk menghindari kondisi hiperkalsiura (kadar kalsium di urin melebihi $300 \mathrm{mg} / \mathrm{hari})$. Faktor yang membantu penyerapan kalsium adalah vitamin D3 (kalsitriol), hormon-hormon seperti paratiroid, hormon pertumbuhan, kalsitonin), $\mathrm{pH}$ yang asam, diet tinggi protein dan banyak laktosa. Faktor yang menjadi penghambat penyerapan kalsium di dalam tubuh adalah $\mathrm{pH}$ alkalis, gangguan absorpsi lemak, serta adanya pitat, fosfat dan oksalat. Kurangnya penyerapan kalsium salah satunya dapat menyebabkan osteoporosis, khususnya bagi wanita yang telah mengalami menopause. Osteoporosis atau tulang keropos yaitu terjadinya pengurangan massa jaringan tulang per unit volume, tulang menjadi tipis, lebih rapuh dan mengandung sedikit kalsium (Kosasih, 2007).

\subsection{Pangan Fungsional}

Pada tahun 1990-an International Life Sciences Institute (ILSI) mengembangkan proyek yang hasilnya disampaikan kepada European Union (EC) khususnya Functional Food Science in Europe (FUFOSE) yang mendefinisikan pangan fungsional sebagai pangan yang dikonsumsi tidak dalam bentuk pil, kapsul atau bentuk suplemen makanan lainnya, serta dapat menunjukkan efek kepuasan dan efek nutrisi yang memadai dan relevan dengan peningkatan keadaan kesehatan dan kesejahteraan dan/atau pengurangan risiko penyakit serta dikonsumsi sebagai bagian dari pola makan normal (Ashwell, 2002).

Industri pangan dunia menghadapi tantangan untuk mengembangkan produk pangan yang diperkaya dengan kualitas nutrisi dan pencegahan penyakit. Kesadaran konsumen mendorong permintaan terhadap produk yang menunjang kesehatan, memperpanjang umur, dan mencegah timbulnya penyakit kronis. $\mathrm{Di}$ Eropa, pengaturan pangan fungsional dilakukan berbeda dari makanan dan obat-obatan media (Gambar 1). Perbedaan utama adalah bahwa makanan fungsional dapat dikonsumsi secara bebas sebagai bagian dari kehidupan sehari-hari. Makanan medis dan obat-obatan digunakan dalam kasus-kasus khusus untuk mengobati atau mengelola suatu kondisi di bawah pengawasan medis (Kozonova \& Povarova, 2015). 


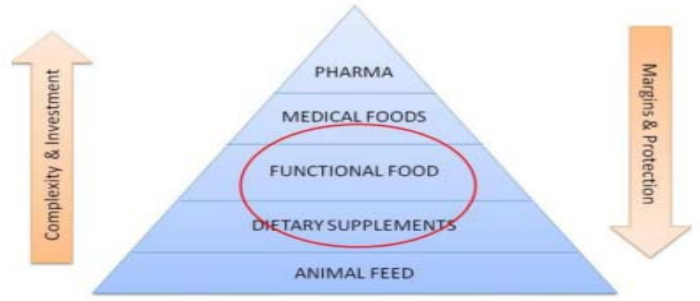

Gambar 1 Posisi pangan fungsional pada piramida pangan (Kozonova \& Povarova, 2015).

Pada tahun 2014 di EU, 58\% konsumen berpikir banyak tentang kesehatan makanan/minuman mereka, $47 \%$ berpikir banyak tentang bahan makanan, dan $40 \%$ sering mengalihkan pikiran mereka ke keamanan makanan. (Kozonova \& Povarova, 2015). Di Jepang, pangan fungsional diperkenalkan dan dikembangkan pada sekitar tahun 1980-an sebagai pangan yang memiliki fungsi fisiologis, termasuk pengaturan biorhytms, sistem saraf, sistem kekebalan tubuh, dan pertahanan tubuh, di luar fungsi nutrisinya (Howlett. J, 2008).

Sampai saat ini, belum ada definisi pangan fungsional yang disepakati secara universal. Masing-masing organisasi di beberapa negara mendefinisikan istilah functional food secara berbeda. Pemerintah Jepang mengenalkan definisi Food for Spesified Health Uses (FOSHU) sebagai pangan yang mengandung bahan atau ingredient yang memiliki fungsi atau efek terhadap kesehatan tubuh secara fisiologis. The Food Quality and Standards services (AGNS) \& Food and Agriculture Organization of the United Nations (FAO) menyebutkan pangan fugnsional bahwa pangan yang ditujukan untuk dikonsumsi sebagai bagian dari diet normal dan mengandung komponen aktif yang berpotensi meningkatkan kesehatan dan mengurangi risiko penyakit. Di Indonesia, pangan fungsional didefinisikan dalam Peraturan Kepala Badan POM RI Nomor HK 0005.52.0685 tentang Ketentuan Pokok Pengawasan Pangan Fungsional, sebagai pangan olahan yang mengandung satu atau lebih komponen fungsional yang berdasarkan kajian ilmiah mempunyai fungsi fisiologis tertentu, terbukti tidak membahayakan dan bermanfaat bagi kesehatan. Peraturan tersebut kemudian diubah menjadi Peraturan Kepala Badan POM RI Nomor 03.1.23.11.11.09909 Tahun 2011 dengan penyesuaian terhadap perkembangan ilmu dan pengetahuan di bidang pangan olahan.

Pangan fungsional didefinisikan sebagai pangan olahan yang mengandung satu atau lebih komponen fungsional yang berdasarkan kajian ilmiah mempunyai fungsi fisiologis tertentu, terbukti tidak membahayakan dan bermanfaat bagi kesehatan. Perkembangan berikutnya adalah perubahan Perka tersebut menjadi
Peraturan Ka BPOM RI Nomor 13 Tahun 2016 tentang Pengawasan Klaim pada Label dan Iklan Pangan Olahan. Di dalam peraturan yang baru tersebut, istilah pangan fungsional tidak didefinisikan kembali.

\subsection{Standardisasi}

Penerapan standar ini juga dimaksudkan untuk dapat memastikan bahwa produk, proses atau jasa memenuhi serangkaian persyaratan yang akan menjamin kualitas yang dihasilkan meskipun seringkali sulit diukur dan diobservasi (Lindlbauer, Schreyögg, \& Winter, 2016).

Standar adalah persyaratan teknis atau sesuatu yang dibakukan, termasuk tata cara dan metode yang disusun berdasarkan konsensus semua pihak/pemerintah/keputusan internasional yang terkait dengan memperhatikan syarat keselamatan, keamanan, kesehatan, lingkungan hidup, perkembangan ilmu pengetahuan dan teknologi, pengalaman, serta perkembangan masa kini dan masa depan untuk memperoleh manfaat yang sebesar-besarnya. Standar Nasional Indonesia yang selanjutnya disingkat SNI adalah Standar yang ditetapkan oleh BSN dan berlaku di wilayah Negara Kesatuan Republik Indonesia (Sekretariat Negara, 2014).

Dalam sudut pandang inovasi, Isharyadi, Susanto, \& Kristiningrum (2017) menyampaikan bahwa terdapat bukti yang kuat bahwa mengembangkan dan mengadopsi standar yang sesuai secara historis merupakan faktor penting dalam komersialisasi inovasi baru. Salah satu keuntungan keterlibatan diproses awal dalam penyusunan sebuah standar adalah sebagai penggerak pertama di dalam sebuah persaingan. Seringkali keberadaan SNI yang tidak sesuai dengan kebutuhan stakeholder dapat menyebabkan inefisiensi ekonomi yang tidak perlu dan mahal.

Proses standardisasi teknologi dan caracara melakukan bisnis adalah kegiatan yang rumit dan memakan waktu, tetapi sangat penting karena besarnya dampak terhadap industri dan masyarakat (Shin, Kim, \& Hwang, 2015). Kemampuan dan kapasitas dalam pengembangan standar sangat berbeda antara negara maju dan negara berkembang. Pada negara maju, kegiatan standardisasi telah mengalami perjalanan yang panjang dan telah mampu mengontrol teknologinya agar sesuai dengan standar, dan sebagai hasilnya konsentrasi pada hukum dan kebijakan ditujukan pada Intelectual Property Right (IPR) dan keterbukaan pada standar ditujukan pada proteksi IPR tersebut. Sedangkan pada negara latecomer atau negara berkembang, kegiatan standardisasi bisa dikatakan relatif baru, sehingga menyebabkan sebagian besar negara berkembang fokus pada strategi standardisasi sebagai standard taker atau free rider atau fast 
follower. Mereka memproduksi barang menggunakan standar yang telah ditetapkan oleh negara maju (Ernst, Lee, \& Kwak, 2014).

Pada saat ini, standar diperlukan tidak hanya untuk menentukan skala dan lingkup ekonomi, tetapi juga untuk mengurangi biaya transaksi dan mencegah duplikasi usaha. Selain itu, standar diperlukan untuk melakukan pertukaran data dan pengetahuan dan untuk memfasilitasi interoperabilitas komponen dan perangkat lunak dalam sistem teknologi yang semakin kompleks (contoh produk smart phone). (Blind, 2009). Standar akan menjadi salah satu alat penting untuk pertumbuhan ekonomi nasional dan strategi konvensional bisnis (Shin et al., 2015).

\section{METODE PENELITIAN}

Penelitian ini menggunakan metode FACTS (a Framework for Analysis, Comparison, and Testing of Standards) yang dikembangkan oleh NIST (National Institute of Standards and Technology, US, Departement of Commerce) (Witherell et al., 2013). Metode ini menyediakan sarana untuk menganalisis, membandingkan dan menguji rancangan standar yang akan dikembangkan dengan mengeksplorasi informasi tambahan yang diperlukan saat pengembangan standar, sehingga proses penyebarluasan dan implementasinya bisa ditingkatkan. Penelitian ini menjelaskan bagaimana memanfaatkan model informasi untuk mengatasi tantangan yang terkait dengan pengembangan dan komunikasi standar. FACTS memperhatikan seluruh kepentingan dari stakeholder yang relevan dan menyediakan kerangka kerja untuk menganalisis, membandingkan dan menguji standar (Amalia, Fahma, Sutopo, \& Pujiyanto, 2018).

Responden yang dipilih adalah stakeholder di bidang pangan fungsional yang mencakup wakil pemerintah, produsen, akademisi yang diidentifikasi menggunakan metode purposive sampling di mana peneliti dibantu seorang ahli melakukan penilaian dalam memilih responden dengan tujuan tertentu (Palys, 2008). Hal ini dilakukan dengan harapan untuk mendapatkan stakeholder dengan kriteria yang seragam. Pengumpulan data dilakukan dalam bentuk Focus Discussion Group (FGD) dan survei ke responden dengan bantuan kuesioner. Responden memberikan tanda centang pada kolom berisi 1-5 skor interval. Nilai dari "1" menunjukkan responden "sangat tidak setuju" sementara "5" menunjukkan pernyataan "sangat setuju".

Analisis lanjutan terhadap hasil kuesioner menggunakan teknik analisis faktor untuk menentukan kelompok variabel yang akan digunakan sebagai usulan persyaratan dalam standar. Tahapan ini dilakukan dengan cara penentuan skoring pada skala objektif dengan pendekatan aturan skala likert menggunakan 5 jumlah pilihan untuk pernyataan yang disampaikan, yaitu sangat setuju (5), setuju (4), netral (3), kurang setuju (2), tidak setuju (1) dengan jumlah pernyataan yang disampaikan sebanyak 19 butir. Analisis ini memenuhi kaidah ilmiah dan secara umum digunakan untuk penentuan dan penilaian skoring suatu instrumen penelitian. (Jatiputro, Setiyaningsih, \& Mulyono, 2015). Rumus umum yang digunakan adalah:

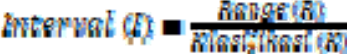

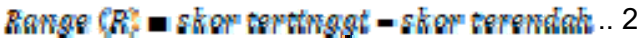

\section{HASIL DAN PEMBAHASAN}

\subsection{Identifikasi data stakeholder}

Kegiatan pengembangan standar dimulai dengan analisis kebutuhan stakeholder terhadap standar. Terdapat 2 (dua) standar yang menjadi kebutuhan stakeholder terhadap standar pangan fungsional, yaitu standar istilah dan definisi serta standar parameter pangan fungsional untuk membantu penyerapan kalsium.

Karakteristik stakeholder yang menjadi responden dalam penelitian ini terlihat pada Gambar 2 yang terdiri dari 42 orang wakil pemerintah, 48 orang wakil akademisi/dosen/peneliti, dan 17 orang wakil produsen.

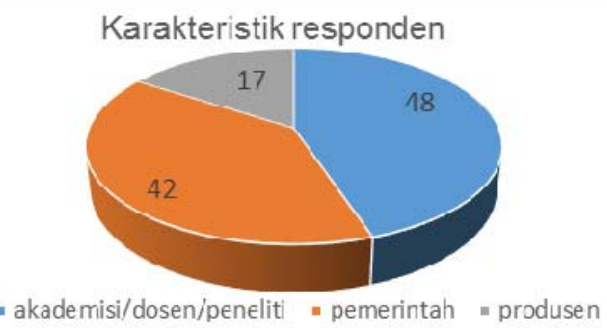

Gambar 2 Karakteristik responden penelitian pangan fungsional.

Sumber: data penelitian, 2018 (diolah).

\subsection{Analisis Teknis}

4.2.1 Dimensi istilah dan definisi pangan fungsional

Nilai rata-rata yang diberikan oleh responden ditunjukkan pada Tabel 2 yang menunjukkan persetujuan responden terhadap seluruh kriteria yang disampaikan, hal ini terlihat dari nilai ratarata di atas kriteria penilaian. Penentuan penilaian dan skoring untuk dimensi ini sebagai berikut:

$$
\begin{array}{ll}
\text { Jumlah pilihan } & =5 \\
\text { Jumlah pernyataan } & =19 \\
\text { Skoring terendah } & =1 \text { (pilihan jawaban } \\
& \text { sangat tidak setuju) }
\end{array}
$$




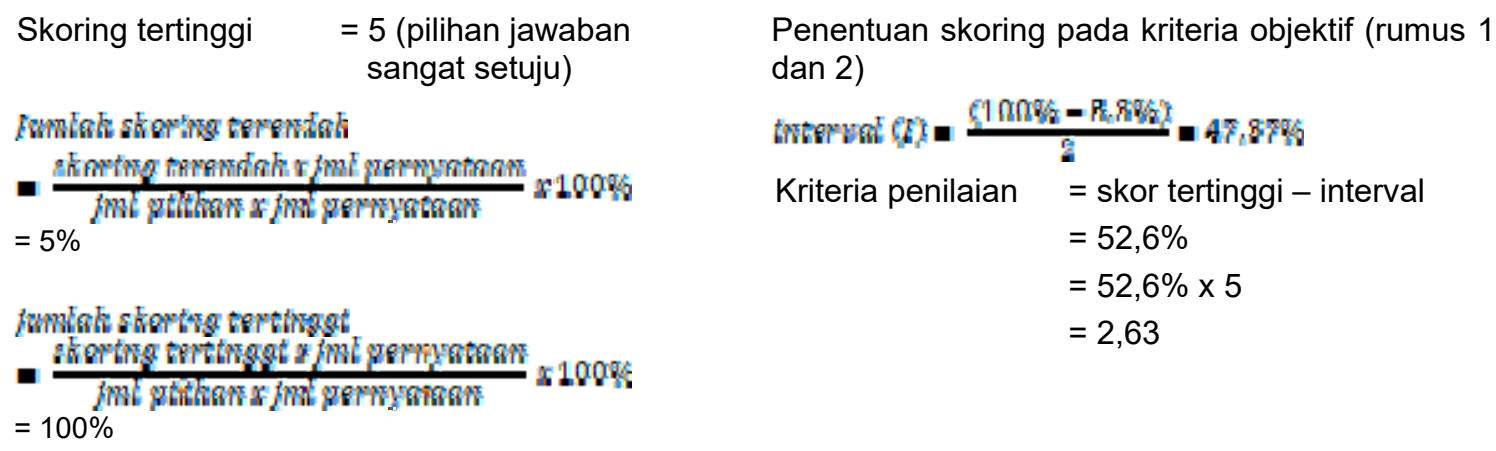
dan 2)

Kriteria penilaian $=$ skor tertinggi - interval

$=52,6 \%$

$=52,6 \% \times 5$

$=2,63$

$=100 \%$

Tabel 2 Nilai rata - rata tanggapan responden. DIMENSI: ISTILAH DAN DEFINISI PANGAN FUNGSIONAL

\begin{tabular}{|c|c|c|}
\hline ATRIBUT & SCORE & NILAI KOMUNAL \\
\hline Pangan & 4.46 & 0.555 \\
\hline Pangan fungsional & 4.54 & 0.494 \\
\hline Pangan segar & 4.00 & 0.358 \\
\hline Pangan olahan & 4.06 & 0.569 \\
\hline Alami dalam pangan & 3.87 & 0.710 \\
\hline Menghilangkan komponen yang membayakan & 4.19 & 0.699 \\
\hline Meningkatkan konsentrasi komponen & 4.21 & 0.716 \\
\hline Menambahkan komponen alami & 4.07 & 0.770 \\
\hline Mengganti komponen & 4.00 & 0.799 \\
\hline Meningkatkan bioavailabilitas atau stabilitas & 4.07 & 0.818 \\
\hline Komponen bioaktif & 4.38 & 0.597 \\
\hline Komponen biomarker & 4.17 & 0.624 \\
\hline Pencegahan resiko penyakit & 4.22 & 0.576 \\
\hline Kajian ilmiah & 3.90 & 0.708 \\
\hline Bukti ilmiah & 4.35 & 0.450 \\
\hline Perkiraan asupan & 4.12 & 0.615 \\
\hline Pola makan sehari-hari & 4.29 & 0.477 \\
\hline Pil & 4.11 & 0.56 \\
\hline Kapsul & 4.05 & 0.757 \\
\hline \multicolumn{3}{|c|}{$\begin{array}{l}\text { DIMENSI: FORMULA PANGAN FUNGSIONAL UNTUK MEMBANTU PENYERAPAN } \\
\text { KALSIUM }\end{array}$} \\
\hline Ruang lingkup & 4.64 & 0.595 \\
\hline $\begin{array}{l}\text { Komposisi utama pangan fungsional untuk membantu penyerapan } \\
\text { kalsium }\end{array}$ & 4.54 & 0.751 \\
\hline Bahan tambahan pangan & 4.53 & 0.828 \\
\hline Kontaminan & 4.53 & 0.738 \\
\hline Higienis & 4.64 & 0.557 \\
\hline Bahan kemasan & 4.64 & 0.733 \\
\hline Isi dalam kemasan & 4.50 & 0.406 \\
\hline Nama produk & 4.53 & 0.736 \\
\hline Bahan penyusun produk & 4.73 & 0.893 \\
\hline Klaim nilai gizi & 4.86 & 0.739 \\
\hline Klaim nilai fungsi & 4.53 & 0.665 \\
\hline Klaim kesehatan & 4.53 & 0.576 \\
\hline Tanggal produksi & 4.73 & 0.644 \\
\hline Instruksi penyimpanan & 4.80 & 0.757 \\
\hline Jumlah yang dikonsumsi & 4.80 & 0.747 \\
\hline Ketentuan tambahan & 4.53 & 0.494 \\
\hline
\end{tabular}

Sumber: data penelitian, 2018 (diolah). 
Analisis lanjutan yang dilakukan adalah mengelompokkan persetujuan responden terhadap atribut yang disampaikan menggunakan bantuan analisis faktor dengan perangkat SPSS 18. Hasil analisis faktor ditemukan 4 kelompok istilah dan definisi pangan fungsional (variable). Penamaan variable disesuaikan dengan kebutuhan penelitian. Dalam penelitian ini, variabel dikelompokkan menjadi:

a. Komponen dan manfaat pangan fungsional, yang didalamnya mendefinisikan tentang defisini pangan fungsional, pangan, pangan segar, pangan olahan, komponen bioaktif, komponen biomarker, dan mengurangi risiko penyakit.

b. Teknologi pembuatan pangan fungsional, yang mendefinisikan 6 cara pembuatan pangan fungsional

c. Cara dan bentuk konsumsi pangan fungsional, didalamnya mendefinisikan tentang definisi pola makan, bentuk pil dan kapsul

d. Pembuktian khasiat, didalamnya mendefinisikan tentang kajian ilmiah, jumlah konsumsi, dan bukti ilmiah.

4.2.2 Dimensi formula pangan fungsional untuk membantu penyerapan kalsium

Jumlah pernyataan yang disampaikan kepada responden sebanyak 16 pernyataan. Penentuan penilaian dan skoring untuk dimensi ini sebagai berikut:

$$
\begin{aligned}
& \text { Jumlah pilihan } \quad=5 \\
& \text { Jumlah pernyataan } \quad=16 \\
& \text { Skoring terendah } \quad=1 \text { (pilihan jawaban } \\
& \text { sangat tidak setuju) } \\
& \text { Skoring tertinggi } \quad=5 \text { (pilihan jawaban } \\
& \text { sangat setuju) }
\end{aligned}
$$

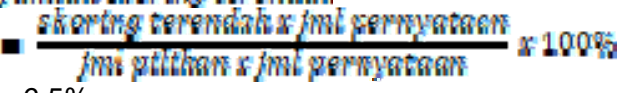

$$
\begin{aligned}
& =6,5 \%
\end{aligned}
$$

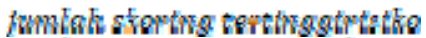

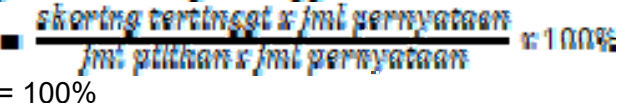

Penentuan skoring pada kriteria objektif (rumus 1 dan 2)

$$
\begin{aligned}
\text { Kriteria penilaian } & =\text { skor tertinggi - interval } \\
& =53,12 \%
\end{aligned}
$$

$$
\begin{aligned}
& =53,12 \% \times 5 \\
& =2,66
\end{aligned}
$$

Berdasarkan nilai rata-rata yang diberikan oleh responden (Tabel 2) dan kriteria penilaian tersebut di atas, dapat disimpulkan responden menyetujui seluruh atribut yang disampaikan di dalam kuesioner.

Analisis faktor yang dilakukan menghasilkan kelompok atribut yang nantinya dapat digunakan sebagai referensi dalam pengembangan standar formula pangan fungsional untuk membantu penyerapan kalsium. Hasil analisis faktor menunjukkan bahwa variabel formula pangan fungsional untuk membantu penyerapan kalsium dapat dikelompokkan menjadi 2 kelompok. Penamaan variabel disesuaikan dengan kebutuhan penelitian. Dalam penelitian ini, variabel dikelompokkan menjadi:

a. Pelabelan, yang didalamnya mengatur tentang bahan penyusun produk, tanggal kadaluwarsa, nama produk, tanggal produksi, instruksi penyimpanan, klaim nilai gizi, klaim nilai fungsi, klaim kesehatan dan isi dalam kemasan.

b. Ruang lingkup dan keamanan pangan, yang didalamnya mengatur tentang komponen utama, BTP, kontaminan, kemasan, higienis dan ruang lingkup.

Pada kelompok pelabelan, atribut isi dalam kemasan memiliki nilai paling kecil, dimana atribut tersebut masih perlu dibahas lebih lanjut jika akan digunakan dalam proses pengembangan standar.

\subsection{Perbandingan Standar}

Tahapan perbandingan standar (Tabel 3) dimaksudkan untuk membandingkan draft standar yang disusun dengan standar negara lain atau internasional yang dijadikan referensi. Perbandingan dilakukan untuk mengidentifikasi kesenjangan dan tumpang tindih standar untuk menghindari duplikasi standar dan digunakan secara harmonis dengan standar yang ada (Rahmawatie, Sutopo, Fahma, \& Nizam, 2017).

\subsection{Pengujian Standar}

Pengujian standar adalah tahapan untuk memvalidasi apakah standar yang diformulasikan dapat diterima secara konsensus oleh para stakeholder. Dalam tahapan pengujian standar ini diharapkan dapat diketahui, apakah stakeholder dapat mengaplikasikannya. Pengujian standar dilakukan melalui forum FGD dengan peneliti yang telah atau sedang melakukan pengembangan pangan fungsional.

Tabel 3 Perbandingan standar.

\begin{tabular}{lcccc}
\multicolumn{1}{c}{ ATRIBUT } & Codex Stan 181- & CODEX STAN & CAC/GL 23- & EU Food Law \\
& 1991 & $203-19951$. & 1997 & \\
\hline Pangan fungsional & Tidak ada & Tidak ada & Tidak ada & Tidak ada \\
Pangan & Tidak ada & Tidak ada & Tidak ada & Tidak ada
\end{tabular}




\begin{tabular}{|c|c|c|c|c|}
\hline ATRIBUT & $\begin{array}{c}\text { Codex Stan 181- } \\
1991 \\
\end{array}$ & $\begin{array}{l}\text { CODEX STAN } \\
203-19951 .\end{array}$ & $\begin{array}{l}\text { CAC/GL 23- } \\
1997\end{array}$ & EU Food Law \\
\hline Pangan segar & Tidak ada & Tidak ada & Tidak ada & Tidak ada \\
\hline Pangan olahan & Tidak ada & Tidak ada & Tidak ada & Tidak ada \\
\hline Komponen bioaktif & Tidak ada & Tidak ada & Tidak ada & Tidak ada \\
\hline Komponen biomarker & Tidak ada & Tidak ada & Tidak ada & Tidak ada \\
\hline Mengurangi resiko penyakit. & Tidak ada & Tidak ada & Tidak ada & Tidak ada \\
\hline Alami dalam pangan & Tidak ada & Tidak ada & Tidak ada & Artikel 3 \\
\hline $\begin{array}{l}\text { Menghilangkan komponen yang } \\
\text { membayakan }\end{array}$ & Tidak ada & Tidak ada & Tidak ada & Artikel 3 \\
\hline Meningkatkan konsentrasi komponen & Tidak ada & Tidak ada & Tidak ada & Artikel 3 \\
\hline Menambahkan komponen alami & Tidak ada & Tidak ada & Tidak ada & Artikel 3 \\
\hline Mengganti komponen & Tidak ada & Tidak ada & Tidak ada & Artikel 3 \\
\hline $\begin{array}{l}\text { Meningkatkan bioavailabilitas atau } \\
\text { stabilitas }\end{array}$ & Tidak ada & Tidak ada & Tidak ada & Artikel 3 \\
\hline Pola makan & Tidak ada & Tidak ada & Tidak ada & Tidak ada \\
\hline Pil & Tidak ada & Tidak ada & Tidak ada & Tidak ada \\
\hline Kapsul & Tidak ada & Tidak ada & Tidak ada & Tidak ada \\
\hline Kajian ilmiah & Tidak ada & Tidak ada & Bagian 3 & Artikel 27 \\
\hline Jumlah konsumsi & Tidak ada & Tidak ada & Tidak ada & Tidak ada \\
\hline Bukti ilmiah & Tidak ada & Tidak ada & Bagian 3 & Tidak ada \\
\hline Bahan penyusun produk & Bagian 9.2 & Bagian 9.2 & Tidak ada & Tidak ada \\
\hline Tanggal kadaluwarsa & Tidak ada & Tidak ada & Tidak ada & Tidak ada \\
\hline Nama produk & Bagian 9.1 & Bagian 9.1 & Tidak ada & Tidak ada \\
\hline Tanggal produksi & Bagian 9.4 & Bagian 9.4 & Tidak ada & Tidak ada \\
\hline Instruksi penyimpanan & Bagian 9.5 & Bagian 9.5 & Tidak ada & Tidak ada \\
\hline Klaim nilai gizi & Tidak ada & Tidak ada & Bagian 4.1 & Tidak ada \\
\hline Klaim nilai fungsi & Tidak ada & Tidak ada & Tidak ada & Tidak ada \\
\hline Klaim kesehatan & Tidak ada & Tidak ada & Bagian 8.1 & Tidak ada \\
\hline Isi dalam kemasan & Bagian 8 & Bagian 7 & Tidak ada & Tidak ada \\
\hline Komponen utama & Bagian 3.1 & Bagian 3.2 & Tidak ada & Tidak ada \\
\hline BTP & Bagian 4 & Bagian 4 & Tidak ada & Tidak ada \\
\hline Kontaminan & Bagian 5 & Bagian 5 & Tidak ada & Tidak ada \\
\hline Kemasan & Bagian 7 & Bagian 7 & Tidak ada & Tidak ada \\
\hline Higienis & Bagian 6 & Bagian 6 & Tidak ada & Tidak ada \\
\hline Ruang lingkup & Bagian 1 & Bagian 1 & Tidak ada & Tidak ada \\
\hline
\end{tabular}

Sumber: data hasil penelitian, diolah (2018)

\subsection{Komposisi utama pangan fungsional untuk membantu penyerapan kalsium}

Tee, Wong, \& Chan (2017) menyebutkan pendekatan CODEX pada pangan fungsional telah dilakukan sejak pertemuan ke $13 \mathrm{FAO} / \mathrm{WHO}$ pada Regional Coordinating Committee for Asia (CCAsia) yang diikuti dengan beberapa pertemuan lanjutan. Codex menetapkan pedoman untuk penggunaan klaim nutrisi yang tercantum dalam CAC/GL 23-1997 yang mencakup tiga jenis klaim, yaitu klaim gizi, klaim fungsi lain dan klaim pengurangan risiko penyakit. Klaim fungsi nutrisi mendeskripsikan peran fisiologis nutrisi dalam pertumbuhan, perkembangan, dan fungsi tubuh. Beberapa contoh klaim nutrisi meliputi:

- Kalsium membantu perkembangan tulang dan gigi

- Vitamin D sangat penting untuk penyerapan dan pemanfaatan kalsium dan fosfor.

Penelusuran komposisi utama pangan fungsional untuk membantu penyerapan kalsium dirumuskan dengan pendekatan expert judgment, yaitu pendapat ahli yang diberikan dalam konteks keputusan (Benini et al., 2017), dan penelusuran penelitian terdahulu.
Kalsium merupakan makro mineral esensial yang sangat vital dan diperlukan tubuh dalam jumlah besar. Sebanyak 99\% Ca terdapat dalam jaringan keras (tulang dan gigi) dan satu persen terdapat dalam jaringan lunak. (Astuti, 2018). Keseimbangan kalsium yang dikonsumsi dan diserap yang positif, mengindikasikan adanya pembentukan tulang. Asupan makanan memiliki peran yang penting dalam hal penyerapan kalsium. (Brouns \& Vermeer, 2000). Kebutuhan kalsium yang tidak terpenuhi dari makanan akan diperoleh dari tulang sehingga tulang dapat mengalami pengeroposan. Absorbsi kalsium dalam makanan cukup rendah ( \pm 20 persen) sangat dipengaruhi berbagai faktor diantaranya kelarutan, hormon, jumlah $\mathrm{Ca}$ dalam jaringan lunak (Astuti, 2018).

FOS (Fructooligosaccharides) campuran GOS/FOS menginduksi efek positif kolon, yang meningkatkan penyerapan $\mathrm{Ca}, \mathrm{P}$, dan $\mathrm{Mg}$. (Bryk et al., 2015). Hal ini didukung penelitian yang dilakukan oleh Scientists di Brasil yang melaporkan bahwa diet fiber, inulin dan FOS dapat meningkatkan penyerapan kalsium 
sebanyak $40 \%$ pada tikus percobaan (Abrams et al., 2018).

Konsumsi sehari-hari kombinasi prebiotik jangka pendek dan panjang rantai fruktan inulin secara signifikan meningkatkan penyerapan kalsium dan meningkatkan mineralisasi tulang selama pertumbuhan pubertas. Efek dari faktor makanan pada penyerapan kalsium dapat dimodulasi oleh faktor genetik, termasuk polimorfisme reseptor vitamin D spesifik (Abrams et al., 2018)

Kopolimer casein phosphopeptides (CPP) CPP dan soluble dietary fiber (SDF) yang disiapkan merupakan kendaraan pengiriman kalsium yang menjanjikan untuk meningkatkan bioavailabilitas kalsium (Gao et al., 2018)

Astuti (2018) menyebutkan komponen aktif yang digunakan untuk perbaikan penyerapan kalsium antara lain:

a. Prebiotik yaitu Fructooligosaccharida yang dapat meningkatkan kelarutan kalsium di dalam usus. Telah digunakan sebagai komponen dalam pengembangan pangan fungsional. Penggunaan FOS 6-9 gram/hari.

b. Vitamin D merupakan vitamin yang dapat membantu penyerapan kalsium dari usus. Telah digunakan dalam beberapa produk pangan fungsional. Di Jepang dianjurkan pemakaian vitamin D 60-200 IU

c. Casein Fosfopeptida. Di usus halus dapat meningkatkan absorpsi kalsium. Telah digunakan dalam FOSHU di Jepang.

\section{KESIMPULAN}

Studi ini memberikan rekomendasi untuk kerangka Standar Nasional Indonesia pangan fungsional mengenai istilah - definisi, dan formula pangan fungsional untuk membantu penyerapan kalsium. Metodologi yang digunakan terdiri dari empat tahap, yaitu analisis pemangku kepentingan, analisis teknis, perbandingan standar, dan pengujian standar.

Dari hasil pengolahan data, dapat disimpulkan untuk dimensi istilah dan definisi pangan fungsional, setidaknya terdapat 4 variabel utama, yaitu:

a. komponen dan manfaat

b. teknologi pembuatan

c. cara dan bentuk konsumsi

d. pembuktian khasiat.

Sedangkan untuk dimensi formula pangan fungsional untuk membantu penyerapan kalsium, setidaknya digolongkan dalam 2 variabel, yaitu:

a. pelabelan b. ruang lingkup keamanan pangan.

Komposisi utama dalam pangan fungsional untuk membantu penyerapan kalsium, setidaknya harus mengandung Prebiotik yaitu Fructooligosaccharida, vitamin D, dan Casein Fosfopeptida. Pengajuan klaim pangan fungsional pada produk harus dibuktikan dengan bukti ilmiah melalui kajian ilmiah dengan melibatkan subjek manusia.

\section{UCAPAN TERIMA KASIH}

Penulis mengucapkan terimakasih kepada Program Insentif Riset Sistem Inovasi Nasional Kemenristekdikti Flagship Gelombang 2 Tahun 2018 berdasarkan Surat Keputusan Nomor 13/EKPT/2018 dan Perjanjian/Kontrak Nomor 3/INS-2/PPK/E4/2018 sebagai sumber pendanaan penelitian ini. Penulis juga mengucapkan terimakasih pada pimpinan Badan Standardisasi Nasional (BSN) yang telah memberikan arahan dan dukungan dalam pelaksanaan penelitian ini. Ucapan terima kasih juga diucapkan kepada narasumber dan responden yang telah bersedia menyumbangkan saran dan pemikiran dalam penelitian ini.

\section{DAFTAR PUSTAKA}

Abrams, S. A., Griffin, I. J., Hawthorne, K. M., Liang, L., Gunn, S. K., Darlington, G., \& Ellis, K. J. (2018). A combination of prebiotic short- and long-chain inulin-type fructans enhances calcium absorption and bone mineralization in young. Am J Clin Nutr 2005;82:471-6, (February).

Amalia, R., Fahma, F., Sutopo, W., \& Pujiyanto, E. (2018). Designing Parameter for Developing Standard of Manual Wheelchair. International Journal of Applied Science and Engineering 2018. 15,2:127-134, 2018(October), 127-134. https://doi.org/10.6703/IJASE.201810

Ashwell, M. (2002). ILSI Europe Concise Monograph Series Functional. ILSI Press.

Astuti, M. (2018). Komponen dan parameter mutu pangan fungsional untuk membantu penyerapan kalsium. Yogyakarta.

Benini, A., Chataigner, P., Noumri, N., Parham, N., Seeney, J., \& Tax, L. (2017). The use of expert judgment in humanitarian analysis Theory, methods and applications. Geneva, Assessment Capacities Project - ACAPS: ACAPS 23, Avenue de France CH-1202 Geneva Switzerlandinfo@acaps.org. 
Blind, K. (2009). Standardisation: a catalyst for innovation. Erasmus Research Institute of Management - ERIM Rotterdam School of Management (RSM) Erasmus School of Economics (ESE) P.O. Box 1738, 3000 DR Rotterdam The Netherlands.

Brouns, F., \& Vermeer, C. (2000). Functional food ingredients for reducing the risks of osteoporosis. Trends in Food Science \& Technology, 11, 22-33.

Bryk, G., Zeni, M., Carlos, C., Patricia, L., Esther, M., Ariel, R., Zeni, S. N. (2015). Effect of a mixture of GOS / FOS $\AA$ on calcium absorption and retention during recovery from protein malnutrition: experimental model in growing rats. European Journal of Nutrition. https://doi.org/10.1007/s00394-0151052-5

Castellini, A., Canavari, M., \& Pirazzoli, C. (2002). Functional Foods In The European Union: An Overview Of The Sector' S Main Issues.

Cooper, C., Westlake, ÆE. S., \& Harvey, ÆE. N. (2006). Review: developmental origins of osteoporotic fracture Review: developmental origins of osteoporotic fracture. Osteoporos Int, 17(March 2015), 337-347. https://doi.org/10.1007/s00198-0052039-5

Ernst, D., Lee, H., \& Kwak, J. (2014). Standards, innovation, and latecomer economic development: Conceptual issues and policy challenges. Telecommunications Policy, 38(10), 853862.

https://doi.org/https://doi.org/10.1016/j.tel pol.2014.09.009

Fikawati, S., \& Syafiq, A. (2005). Faktor-faktor yang berhubungan dengan asupan kalsium pada remaja di kota bandung. Jurnal Kedokteran Trisakti Universa Medicina, 24(January-Maret), 1-19.

Gao, A., Dong, S., Chen, Y., Chen, G., Li, S., \& Chen, Y. (2018). Food Hydrocolloids In vitro evaluation and physicochemical characteristics of casein phosphopeptides-soluble dietary fi bers copolymers as a novel calcium delivery system. Food Hydrocolloids, 79, 482490.

https://doi.org/10.1016/j.foodhyd.2018.01 .024

Gropper, S. S., Smith, J. L., \& Groff, J. L. (2009). Dietary Reference Intakes (DRI). Wadsworth.
Harnedy, A., \& Fitzgerald, R. J. (2012). Bioactive peptides from marine processing waste and shellfish: A review. Journal of Functional Foods, 4, $6-24$.

https://doi.org/10.1016/j.jff.2011.09.001

Herminiati, A., Rimbawan, Nurhayu, Mulyati, Z. S., \& Astuti, D. A. (2013). Efektifitas inumin untuk meningkatkan penyerapan kalsium pada model tikus defisiensi kalsium. In Forum IPIMA Ikatan Profesor indonesia - Malaysia.

Hoeger, W. W. ., \& Goeger, S. A. (2005). Lifetime Physical Fitness \& Wellness. Thomson Wadsworth, USA.

Howlett, J. (2008). Functional Foods. ILSI Europe a.i.s.b.l.

Isharyadi, F., Susanto, D. A., \& Kristiningrum, E. (2017). Role and economic benefit of standards and innovations implementation. In Prosiding Pertemuan dan Presentasi IImiah Standardisasi 2 (pp. 31-42).

Jatiputro, A. H., Setiyaningsih, I., \& Mulyono, G. S. (2015). Comprehension of high $s$ chool $s$ tudent about $r$ oad $m$ arking and $t$ raffic $r$ egulation. Eco Rekayasa, 11(Maret), 54-60.

Jonas, M. S., \& Beckmann, S. C. (1998). Functional Foods: Denmark and England.

Kosasih, A. S. (2007). Hubungan asupan kalsium, aktivitas fisik, paritas, indeks massa tubuh dan kepadatan tulang pada wanita pascamenopause. Universitas Diponegoro Semarang.

Kozonova, J., \& Povarova, N. (2015). Leading trends in the european functional food market. Холодильна Техніка Та Технологія, 51(4), 2-6. https://doi.org/10.15673/04538307.4/2015.44785

Lindlbauer, I., Schreyögg, J., \& Winter, V. (2016). Changes in technical efficiency after quality management certification: A $D E A$ approach using difference-indifference estimation with genetic matching in the hospital industry \&. European Journal If Operation Research, 250 , 1026-1036. https://doi.org/10.1016/j.ejor.2015.10.029

Marsono, Y. (2008). Prospek Pengembangan Makanan Fungsional, 7(1), 19-27.

Palys, T. (2008). Purposive sampling. In L. M. Given (Ed.), 2.

Rahmawatie, B., Sutopo, W., Fahma, F., \& Nizam, M. (2017). Designing Framework 
for Standardization and Testing Requirements of Battery Management System for Electric Vehicle Application. In 2017 4th International Conference on Electric Vehicular Technology (ICEVT) (pp. 7-12).

Sekretariat Negara. Undang-Undang Nomor 20 Tahun 2014 - Standardisasi dan Penilaian Kesesuaian (2014).

Shin, D.-H., Kim, H., \& Hwang, J. (2015). Standardization revisited: A critical literature review on standards and innovation. Computer Standards \& Interfaces, 38, 152-157. https://doi.org/https://doi.org/10.1016/j.csi .2014.09.002

Tee, E. S., Wong, J., \& Chan, P. (2017). Functional Foods Monograph 2017. International Life Sciences Institute (ILSI) Southeast Asia Region.
Trilaksani, W., Salamah, E., \& Nabil, M. (2006). Pemanfaatan limbah tulang ikan tuna sebagai sumber kalsium dengan metode hidrolisis protein. Buletin Teknologi Hasil Perikanan, Nomor 2, IX, 34-45.

Witherell, P., Lee, J. H., Witherell, P., \& Lee, J. H. (2013). NISTIR 7935 FACTS: A Framework for Analysis, Comparison , and Testing of Standards NISTIR 7935 FACTS: A Framework for Analysis, Comparison, and Testing of Standards.

Wong, A. Y., Ming, J., Lai, C., Chan, A. W., Chan, A. W., Property, I., \& Sar, H. K. (2015). Regulations and protection for functional food products in the United States. Journal of Functional Foods, 17, 540-551.

https://doi.org/10.1016/j.jff.2015.05.038 
Jurnal Standardisasi Volume 21 Nomor 1, Maret 2019: Hal 19 - 30 